$\mathrm{Oz}$

Volume 28

Article 3

$1-1-2006$

\title{
A Church in Filadelfia, Costa Rica
}

Jae Cha

Follow this and additional works at: https://newprairiepress.org/oz

(c) (i) $(9)$

This work is licensed under a Creative Commons Attribution-Noncommercial-No Derivative Works 4.0 License.

\section{Recommended Citation}

Cha, Jae (2006) "A Church in Filadelfia, Costa Rica," Oz: Vol. 28. https://doi.org/10.4148/2378-5853.1428

This Article is brought to you for free and open access by New Prairie Press. It has been accepted for inclusion in Oz by an authorized administrator of New Prairie Press. For more information, please contact cads@k-state.edu. 


\section{A Church in Filadelfia, Costa Rica}

Jae Cha
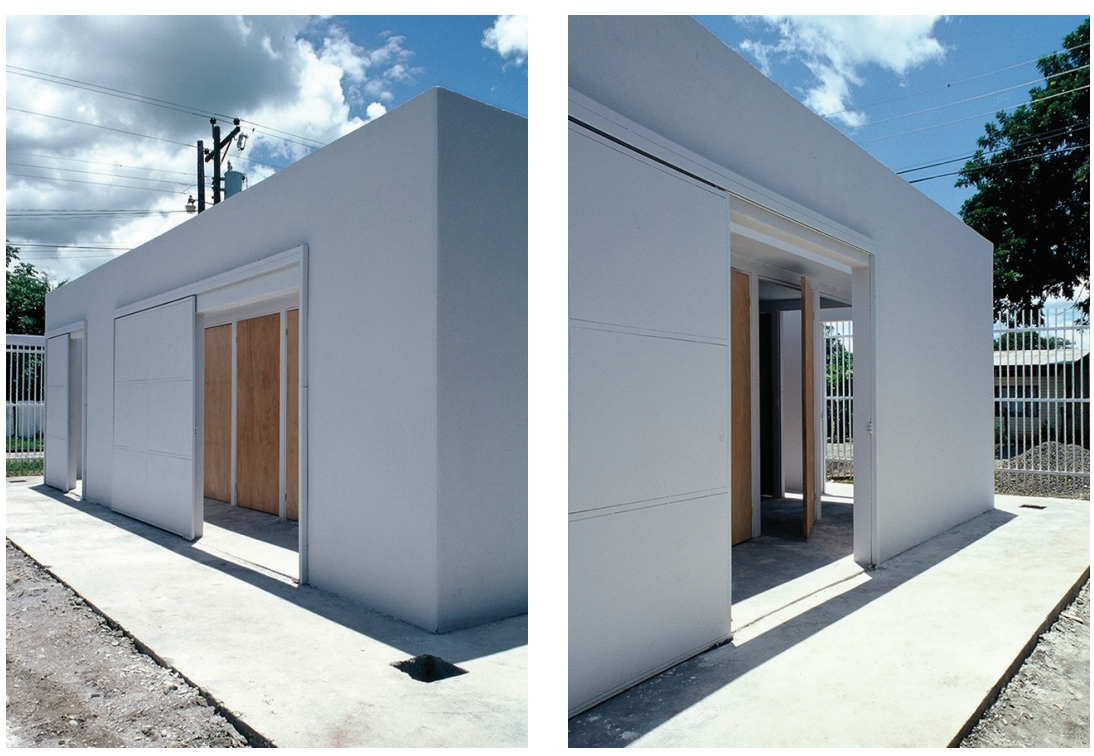

This project is being built in Filadelfia, Costa Rica, a northern town near Liberia. The site is in a residential neighborhood that has "permanent" houses. In order to try to build within that context, we proposed a church building that used local concrete and wood similar to the existing houses.

The plan of the building is simple. There are two rectangles, one inside of each other. The exterior wall is a concrete layer with sliding entry doors and the interior wall is repetitive wooden doors. The reason for these two walls was because the client was concerned about the security, and wanted a very heavy structure made of concrete or brick. My personal preference was to use a lighter material for the walls that would allow for natural light and ventilation to occur, since this part of Costa Rica was very hot and humid in the summers.

A compromise was reached, and both the client and I were satisfied by having two layers: a heavy exterior layer for security and a lighter interior layer for light and wind penetration. In between these two layers, we proposed a corridor zone where it was open to the sky, allowing for light and air to move through the walls freely. Depending on what the weather was that day, the doors can be fixed or can swing freely, allowing for the interior of the space to receive different conditions of light and wind. During the day, the space becomes animated by the changing patterns of light on the door and the amount of breeze that blows through the space-a metaphor for the "Holy

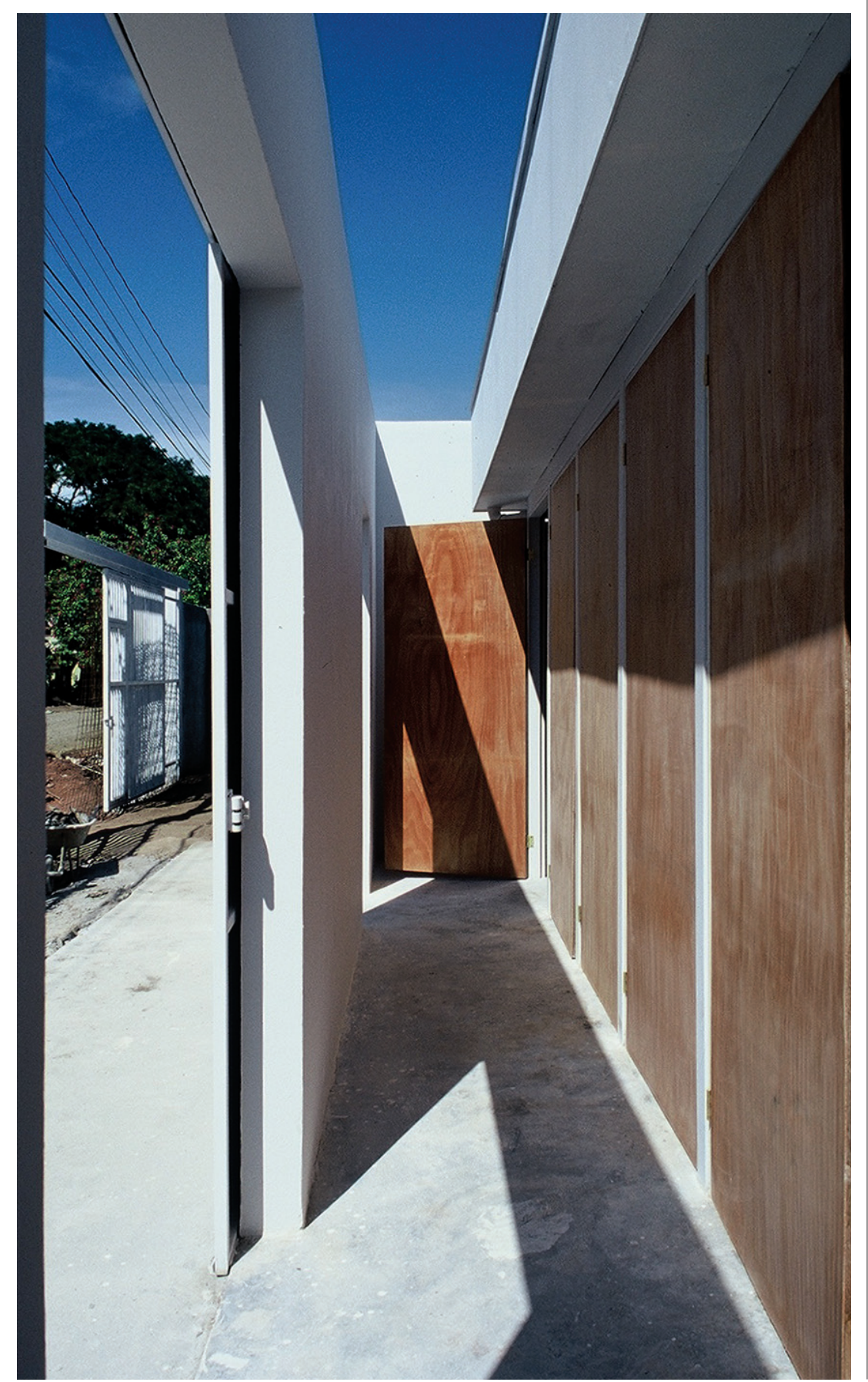



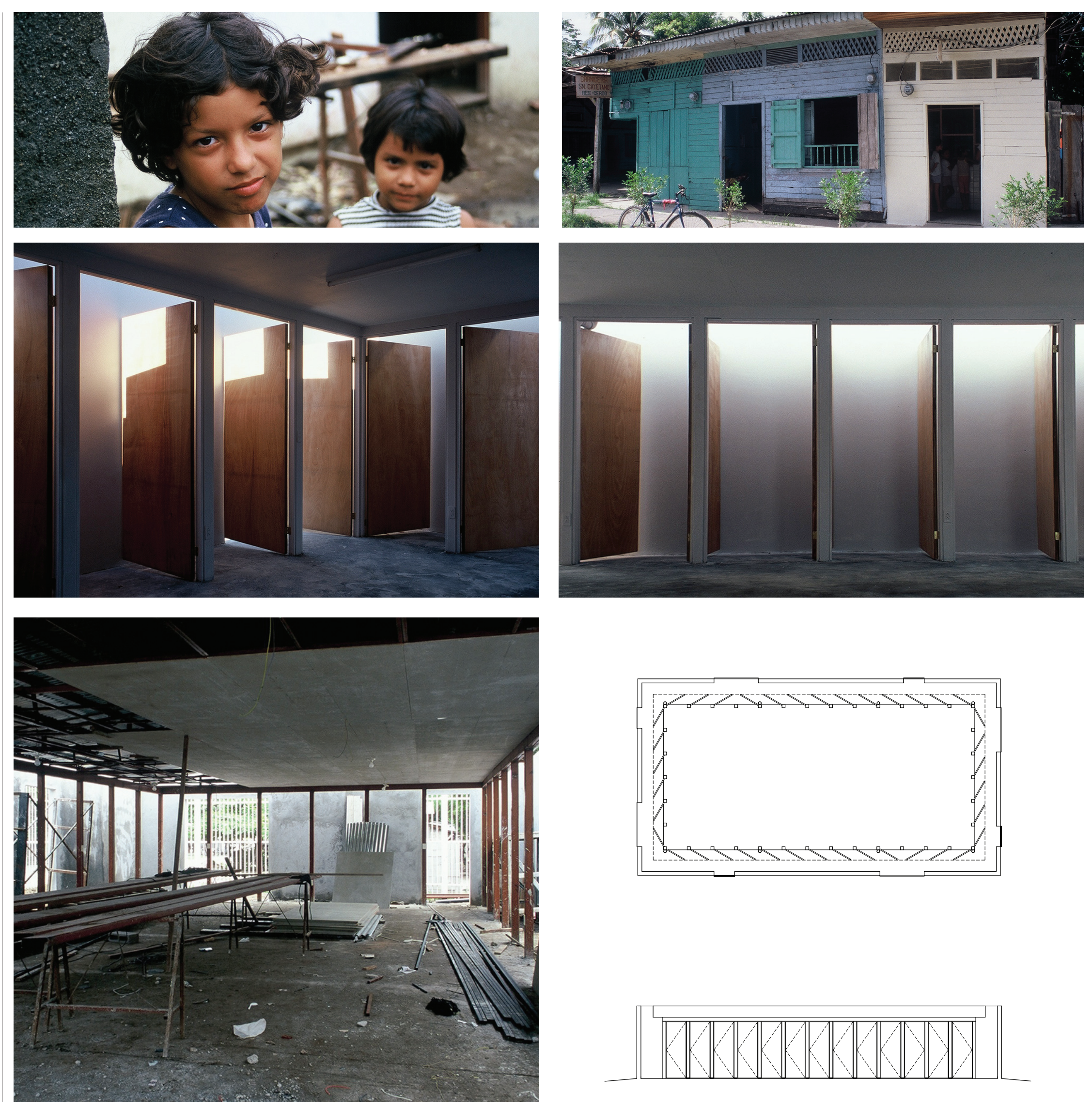